\title{
Plastic and Stable Electrophysiological Properties of Adult Avian Forebrain Song-Control Neurons across Changing Breeding Conditions
}

\author{
John Meitzen, ${ }^{1}$ Adam L. Weaver, ${ }^{2}$ Eliot A. Brenowitz, ${ }^{3,4}$ and David J. Perkel ${ }^{2,3}$ \\ ${ }^{1}$ Program in Neurobiology and Behavior and Departments of ${ }^{2}$ Otolaryngology, ${ }^{3}$ Biology, and ${ }^{4}$ Psychology, University of Washington, Seattle, \\ Washington 98195
}

\begin{abstract}
Steroid sex hormones drive changes in the nervous system and behavior in many animal taxa, but integrating the former with the latter remains challenging. One useful model system for meeting this challenge is seasonally breeding songbirds. In these species, plasma testosterone levels rise and fall across the seasons, altering song behavior and causing dramatic growth and regression of the song-control system, a discrete set of nuclei that control song behavior. Whereas the cellular mechanisms underlying changes in nucleus volume have been studied as a model for neural growth and degeneration, it is unknown whether these changes in neural structure are accompanied by changes in electrophysiological properties other than spontaneous firing rate. Here we test the hypothesis that passive and active neuronal properties in the forebrain song-control nuclei HVC and RA change across breeding conditions. We exposed adult male Gambel's white-crowned sparrows to either short-day photoperiod or long-day photoperiod and systemic testosterone to simulate nonbreeding and breeding conditions, respectively. We made whole-cell recordings from RA and HVC neurons in acute brain slices. We found that RA projection neuron membrane time constant, capacitance, and evoked and spontaneous firing rates were all increased in the breeding condition; the measured electrophysiological properties of HVC interneurons and projection neurons were stable across breeding conditions. This combination of plastic and stable intrinsic properties could directly impact the song-control system's motor control across seasons, underlying changes in song stereotypy. These results provide a valuable framework for integrating how steroid hormones modulate cellular physiology to change behavior.
\end{abstract}

\section{Introduction}

Steroid sex hormones change adult animal behavior and modulate the underlying neural substrates (Bass and Zakon, 2005; Cooke and Woolley, 2005a; Pfaff et al., 2008; Sengelaub and Forger, 2008; Zornik and Yamaguchi, 2008), but it is unclear how hormone action at the cellular level alters behavior. One useful model for addressing this topic is seasonal plasticity in vertebrate brains (Tramontin and Brenowitz, 2000). In many species, steroid sex hormones induce changes in the structure and electrophysiology of brain regions that control behaviors related to reproduction. Although seasonally breeding species are found in every vertebrate class, one group stands out as a model system: seasonally breeding songbirds.

\footnotetext{
Received Nov. 20, 2008; revised April 9, 2009; accepted April 16, 2009.

This work was supported by National Institutes of Health Grants MH068530 and MH066128 (D.J.P.), MH53032 (E.A.B.), 5 T32 GM07108 (J.M.), and P30-DC04661 (E. W Rubel) and by a National Science Foundation Graduate Research Fellowship (J.M.). We thank Karin Lent and Kristen Richards for technical assistance and bird care, Joseph Sisneros for comments on a previous version of this manuscript, Jeremy Atherton and Mark Bevan for sharing their script for action potential threshold detection, and the members of the Perkel and Brenowitz laboratories for critical discussion and support.

Correspondence should be addressed to John Meitzen at his present address: Department of Neuroscience, University of Minnesota, 6-145 Jackson Hall, 321 Church Street SE, Minneapolis, MN 55455. E-mail: meitz010@umn.edu.

A. L. Weaver's present address: Division of Basic Pharmaceutical Sciences, Xavier University, New Orleans, LA 70125.

DOI:10.1523/JNEUROSCI.5571-08.2009

Copyright $\odot 2009$ Society for Neuroscience $\quad$ 0270-6474/09/296558-10\$15.00/0
}

Seasonally breeding songbirds are uniquely advantageous because they show dramatic sex steroid hormone-induced seasonal changes in song, a learned, quantifiable behavior with a known function, and in the song-control system (see Fig. 1), a discrete set of nuclei that controls song behavior (Nottebohm, 1981; Ball et al., 2004; Brenowitz, 2004). In the high-latitude seasonally breeding songbirds such as the Gambel's white-crowned sparrow studied here, increasing day length after the winter solstice stimulates gonadal growth, resulting in higher plasma levels of testosterone (T) and its estrogenic and androgenic metabolites. These steroid sex hormones bind to the androgen and estrogen receptors located in all of the major song nuclei (see Fig. 1), causing pronounced changes in neuronal morphology and nucleus volume. The volume of the forebrain premotor song-control nucleus HVC (HVC used as a proper name) (see Fig. 1) (Reiner et al., 2004), for example, increases primarily by recruitment of new neurons (Alvarez-Buylla et al., 1988; Brenowitz, 2004). Growth of HVC's target nucleus RA is dependent on a trans-synaptic signal from HVC (Brenowitz and Lent, 2001, 2002; Meitzen et al., $2007 \mathrm{~b}$ ) that increases RA neuronal soma size and dendritic arbor (Hill and DeVoogd, 1991; Brenowitz, 2004).

Although the cellular mechanisms underlying changes in nucleus volume have long been studied as a model for neural plasticity, the effect of breeding condition upon the electrical activity of neurons in the song-control nuclei has not been examined, other than the spontaneous firing rate of RA neurons (Park et al., 
2005; Meitzen et al., 2007a,b) and the auditory responses of HVC cells to different acoustic stimuli (Del Negro et al., 2005). Here we tested the hypothesis that the passive and active electrophysiological properties of neurons in HVC and RA change across breeding conditions. We exposed adult Gambel's white-crowned sparrows to either nonbreeding or breeding cues in the laboratory and recorded from neurons in RA and HVC using the whole-cell configuration in acute brain slices. We found that the electrophysiological properties of RA neurons change across breeding condition, whereas the electrophysiological properties of HVC neurons remain stable. RA is an important premotor nucleus, and these changes in its intrinsic properties could directly modify the motor control of song production across seasons, resulting in changes in song stereotypy.

\section{Materials and Methods}

Animals

The Institutional Animal Care and Use Committee at the University of Washington approved all procedures used in this study. We collected 44 adult male Gambel's white-crowned sparrows (Zonotrichia leucophrys gambelii) in eastern Washington during their autumnal migrations from 2003 to 2006. We housed the birds in outdoor aviaries for up to 30 weeks before placing them in indoor aviaries. Once indoors, they were exposed to a short-day (SD) photoperiod ( $8 / 16 \mathrm{~h}$ light/dark cycle) for at least 10 weeks before use to ensure that they were photosensitive and therefore responsive to circulating plasma $\mathrm{T}$ and the long-day (LD) photoperiod typical of their Alaskan breeding grounds (20/4 h light/dark cycle). Birds kept on the SD photoperiod maintain regressed testes and song nuclei, a low intrinsic spontaneous firing rate in RA, a low song rate, and basal levels of T typical of the nonbreeding season (Smith et al., 1995; Tramontin et al., 2000; Brenowitz, 2004; Park et al., 2005; Meitzen et al., 2007a, 2009). Food and water were available ad libitum throughout the experiment. During the initial 10 weeks of SD photoperiod exposure, birds were housed in groups in indoor aviaries and could see and hear the other birds housed in the same room.

\section{Systemic hormone and photoperiod manipulations}

Some birds were implanted subcutaneously with single capsules of $\mathrm{T}$ and exposed to the $\mathrm{LD}$ photoperiod for $21 \mathrm{~d}$. Birds exposed to systemic $\mathrm{T}$ and the LD photoperiod exhibit larger song nuclei, high spontaneous firing rates in RA, high song rates, and increased song stereotypy typical of the breeding season (Smith et al., 1995; Tramontin et al., 2000; Brenowitz, 2004; Park et al., 2005; Meitzen et al., 2007a, 2009). We exposed birds to both the LD photoperiod and systemic T to recreate the two most important seasonal influences on white-crowned sparrows: elevated T levels and LD photoperiod typical of their Alaskan breeding grounds $(20 \mathrm{~h}$ of light per day). Also, exposure to the LD photoperiod accelerates the T-induced changes in cellular physiology (Meitzen et al., 2007b). Regardless of whether the birds are exposed to the LD or SD photoperiod, T exposure alone induces the increased spontaneous firing rates, soma size, and nucleus size typical of the breeding season (Smith et al., 1997; Meitzen et al., 2007b). T implants were made from SILASTIC tubing (inner diameter, $1.0 \mathrm{~mm}$; outer diameter, $2.0 \mathrm{~mm}$; length, $12 \mathrm{~mm}$; VWR) filled with crystalline T, as described by Tramontin et al. (2003). The implants were rinsed with ethanol and soaked overnight in $0.1 \mathrm{M}$ PBS before implantation. Birds housed on the LD photoperiod were implanted with $\mathrm{T}$ because exposure of wild-caught birds to the LD photoperiod alone in the laboratory does not elevate circulating $\mathrm{T}$ levels into the physiological breeding range observed in wild Gambel's white-crowned sparrows (4-25 ng/ml) (Wingfield and Farner, 1978; Wingfield and Moore, 1987; Smith et al., 1995; Park et al., 2005). All other groups were maintained on the SD photoperiod to mimic conditions in their winter range. Birds maintained on the SD photoperiod were not castrated before implantation because they have regressed testes that have been shown not to secrete significant levels of T (Smith et al., 1995; Tramontin et al., 2000). We note that circulating steroid hormone levels are not necessarily identical to those in the brain parenchyma because of local neurosteroid synthesis and metabolism (Schlinger and London, 2006). Although ste-
Table 1. Plasma T level

\begin{tabular}{llc}
\hline Treatment group & Number of animals & $\begin{array}{l}\text { Plasma T level } \\
(\mathrm{ng} / \mathrm{ml})\end{array}$ \\
\hline SD & 15 & $0.36 \pm 0.06^{\mathrm{a}}$ \\
LD and systemic T & 18 & $12.80 \pm 1.12^{\mathrm{b}}$ \\
\hline
\end{tabular}

Values are mean \pm SEM. Different superscript letters denote significant differences $(p<0.0001)$.

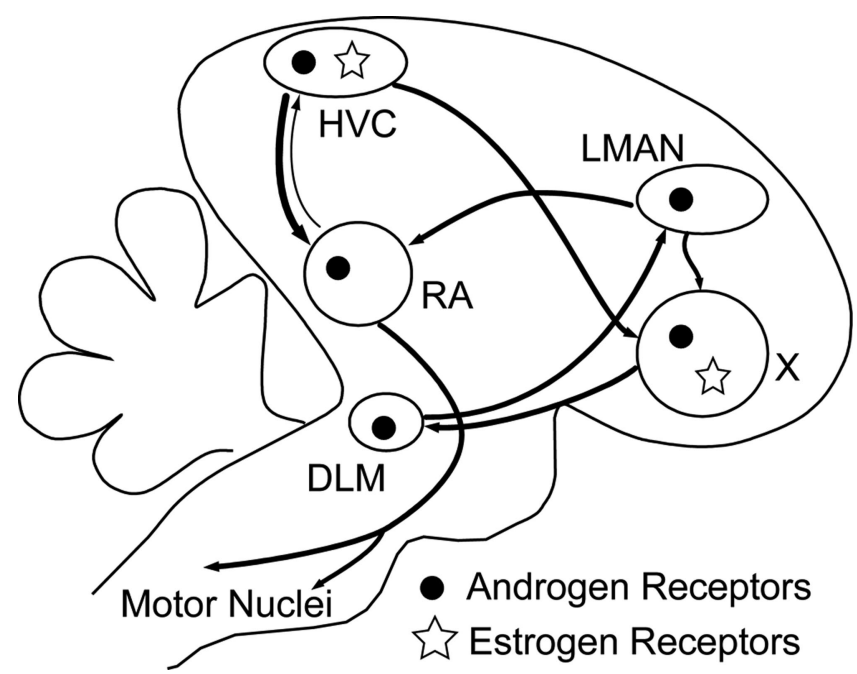

Figure 1. Simplified schematic of the avian song-control system, including steroid receptor distribution. HVC and RA comprise the descending telencephalic motor circuit. RA projects to the brainstem motoneurons (including $\mathrm{nXIlts)}$ that control the muscles involved with respiration and the sound production organ, the syrinx. RA also projects back to HVC (Roberts et al., 2008). HVC, X, DLM, and LMAN comprise the anterior forebrain pathway, which is necessary for song learning and some forms of adult song plasticity. DLM, Medial portion of the dorsolateral nucleus of the anterior thalamus; $\mathrm{nXIIts,} \mathrm{the} \mathrm{tracheosyringeal} \mathrm{portion} \mathrm{of} \mathrm{the} \mathrm{hypoglossal} \mathrm{nu-}$ cleus; RA, robust nucleus of the arcopallium; $X$, Area $X$, a subdivision of the medial striatum. Nomenclature used here follows Reiner et al. (2004). We note that only androgen receptor mRNA and estrogen-concentrating cells have ben detected in Area X.

roids can exert both acute and long-term effects after cellular physiology, the relatively long time course required to induce changes in RA spontaneous firing rate (Meitzen et al., 2007b), song behavior (Meitzen et al., 2009), and other song control system attributes (Tramontin et al., 2000; Meitzen et al., 2007b) suggest that the cellular properties studied here are not attributable to acute steroidal action.

\section{Electrophysiology}

Preparation of brain slices. Methods for preparing slices have been described previously (Park et al., 2005). Briefly, each animal was anesthetized with isoflurane and killed by decapitation. The brain was dissected rapidly into ice-cold, oxygenated artificial CSF (ACSF) containing the following (in mM): $119 \mathrm{NaCl}, 2.5 \mathrm{KCl}, 1.3 \mathrm{MgSO}_{4}, 2.5 \mathrm{CaCl}_{2}, 1 \mathrm{NaH}_{2} \mathrm{PO}_{4}$, $16.2 \mathrm{NaHCO}_{3}, 11 \mathrm{D}$-glucose, and $10 \mathrm{HEPES}$, osmolarity adjusted to $300-$ $310 \mathrm{mOsm}$ with sucrose. Parasagittal or coronal brain slices $(300 \mu \mathrm{m}$ thick) were prepared using a Vibratome (Vibratome), and slices were stored at room temperature submerged in bubbled ACSF in which HEPES was replaced with equiosmolar $\mathrm{NaHCO}_{3}$. All chemicals were obtained from Sigma-Aldrich.

Electrophysiological recording. Recording procedures have been described previously (Farries et al., 2005; Meitzen et al., 2007a,b). After resting for at least $1 \mathrm{~h}$ after sectioning, slices were placed in a recording chamber and superfused with ACSF heated to $28-30^{\circ} \mathrm{C}$. We established whole-cell recordings using the "blind" method (Blanton et al., 1989) from neurons within a region that could be reliably identified as HVC or RA using transillumination. Pipettes had a resistance of 4-8 M $\Omega$ and were filled with a solution containing (in $\mathrm{mM}$ ) $120 \mathrm{~K}$ methylsulfate, 10 HEPES, 0.2 EGTA, $8 \mathrm{NaCl}, 2 \mathrm{MgCl}_{2}$, 2 ATP, $0.3 \mathrm{GTP}$, and 12.75 phosphocreatine. Osmolarity and $\mathrm{pH}$ were adjusted to $295-305 \mathrm{mOsm}$ and 
7.2-7.4, respectively, and 0.5\% biocytin (Sigma) was added. In RA, 11 neurons were recorded using the gramicidin-perforated patch technique, following previously published protocols (Ding and Perkel, 2002; Person and Perkel, 2005; Solis and Perkel, 2006). The internal solution was identical to that used in the whole-cell configuration, except for the addition of gramicidin in the electrode tip. Signals were amplified with either an Axoclamp 2B (Molecular Devices) followed by a Brownlee Model 410 amplifier (Brownlee Precision) or a MultiClamp 700B (Molecular Devices). Signals were low-pass filtered at $5 \mathrm{kHz}$ and digitized at $10 \mathrm{kHz}$ with either a National Instruments digitizing board and stored on a personal computer using a custom data acquisition program written in LabView (National Instruments) by M. A. Farries and D. J. Perkel or a Digidata 1322A (Molecular Devices) and stored on a personal computer using pClamp 9 (Molecular Devices). Membrane potentials were corrected for a liquid junction potential of $+5 \mathrm{mV}$, following Farries et al. (2005).

Data analysis. Basic electrophysiological properties and action potential characteristics were analyzed using pClamp 9, a custom IGOR (Wavemetrics) program written by M. A. Farries, and a custom Spike2 (Cambridge Electronic Design) program written by A. L. Weaver. For most properties measured, we followed the definitions of Farries and colleagues $(2000,2002,2005)$. We used different methods to calculate the firing rates, action potential threshold, input resistance, membrane time constant, and capacitance. Spontaneous firing rate was calculated using a cell-attached configuration, before patch rupture, in the time after the spontaneous firing rate stabilized after cell sealing. Evoked firing rates were measured after patch rupture. The evoked firing rate is defined as the number of action potentials evoked over the duration of the current injection. We defined initial firing rate as the inverse of the first interspike interval and steady-state firing rate as the average firing rate over the last $400 \mathrm{~ms}$ of the current pulse (Gale and Perkel, 2006). Action potential threshold was detected using a custom algorithm described previously by Baufreton et al. (2005). Briefly, the algorithm detected the first point of sustained positive "acceleration" of voltage $\left(\delta^{2} V / \delta t^{2}\right)$ that was also more than four times the SD of membrane noise before the detected threshold. The input resistance was calculated from the steady-state membrane potential in response to $-0.02 \mathrm{nA}$ hyperpolarizing pulses. Some neurons exhibited "sag," a time-dependent inward rectification in which the hyperpolarized membrane potential gradually depolarizes to steady state. We analyzed sag by calculating the "sag index" as described by Farries et al. (2005). Briefly, sag index is the difference between the minimum voltage achieved during the largest hyperpolarizing current pulse (i.e., the membrane potential at the bottom of the sag) and the steady-state voltage deflection of that pulse, divided by the steady-state voltage deflection. Thus, a cell with no sag would have a sag index of 0 , whereas a cell whose maximum voltage deflection is twice that of the steady-state deflection would have a sag index of 1 . Cells with considerable sag typically have an index of $\geq 0.1$. The membrane time constant was calculated by fitting a single exponential curve to the membrane potential change in response to $-0.02 \mathrm{nA}$ hyperpolarizing pulses. Membrane capacitance was calculated using the following equation: capacitance $=$ membrane time constant/input resistance.

\section{Hormone assay}

On the day of each electrophysiological recording, we collected blood from each subject into a heparinized microhematocrit tube and stored it on ice until centrifugation (within $1 \mathrm{~h}$ ). We harvested the plasma and stored it at $-20^{\circ} \mathrm{C}$ for subsequent steroid radioimmunoassay (RIA). To measure circulating $\mathrm{T}$, we followed the RIA protocol of Tramontin et al. (2001), using a Coat-a-Count total testosterone RIA kit (Diagnostic Products). The minimum detectable plasma T concentration was 0.2 $\mathrm{ng} / \mathrm{ml}$, and the maximum was $16 \mathrm{ng} / \mathrm{ml}$. Some samples were lost because of a $\mathrm{T}$ assay failure, and some were lost because too little plasma was collected for accurate analysis.

\section{Brain histology}

At the end of the recording session, we fixed each slice overnight in $4 \%$ paraformaldehyde solution in $0.1 \mathrm{M}$ phosphate buffer $(\mathrm{PB})$ at $4^{\circ} \mathrm{C}$. The slices were then briefly washed with $0.1 \mathrm{M} \mathrm{PB}$, cryoprotected in $30 \%$ sucrose in $0.1 \mathrm{M} \mathrm{PB}$, and resectioned to a thickness of $50 \mu \mathrm{m}$ using a freezing microtome. Biocytin-filled neurons were visualized by processing with the avidin/biotin/horseradish peroxidase kit (ABC Elite kit; Vector Laboratories) using diaminobenzidine (Sigma) as the peroxidase substrate, as in the study by Farries et al. (2005).

\section{Statistics}

We used two-way ANOVAs with a Tukey's post hoc test to assess the effects of breeding condition and cell type on HVC characteristics. We performed two-tailed $t$ tests for comparing RA characteristics across breeding conditions. For comparisons of cumulative frequency distributions, we used the nonparametric Kolmogorov-Smirnov two-sample test, with an $\alpha$ level of 0.05 . For comparisons of the slopes of linear regressions, we used the Student's two-tailed $t$ test method (Zar, 1999). We fit an exponential curve using the formula $Y=Y_{\max }{ }^{\star}(1-$ $\left.\exp \left(-K^{\star} X\right)\right)$, which starts at zero and ascends to asymptote $\left(Y_{\max }\right)$ with a rate constant $(K)$. We used $\mathrm{F}$ tests to compare whether the fits of exponential curves differed significantly. Statistics were calculated using Prism 5.0 (GraphPad Software), Excel 2002 (Microsoft), or SigmaStat 3.00 (SPSS).

\section{Results}

\section{Plasma T levels}

SILASTIC T pellets implanted subcutaneously significantly increased plasma levels of $\mathrm{T}$ into the physiological breeding range seen in wild adult male Gambel's white-crowned sparrows under breeding conditions (Table 1$)(p<0.0001)$. T levels were basal in the groups that did not receive systemic T implants (Table 1).

\section{Electrophysiological properties of RA neurons}

We recorded from 33 projection neurons in RA from 15 birds exposed to the SD photoperiod and 33 neurons from 18 birds exposed to the LD photoperiod and systemic T. Projection neurons are the predominant cell type in RA and receive glutamatergic input from HVC and lateral magnocellular nucleus of anterior nidopallium (LMAN) (Fig. 1) (Mooney and Konishi, 1991; Mooney, 1992; Spiro et al., 1999; Stark and Perkel, 1999; Sizemore and Perkel, 2008). They in turn send glutamatergic projections to brainstem vocal control and respiratory motoneurons (Fig. 1) (Vicario, 1991; Wild, 1993) and collaterals to other RA neurons (Herrmann and Arnold, 1991; Spiro et al., 1999; Sizemore and Perkel, 2008). A small number of RA neurons also project to HVC (Fig. 1) (Roberts et al., 2008). Electrophysiological and morphological properties of white-crowned sparrow projection neurons in RA (Fig. $2 A, B$; Table 2) are similar to those reported in the zebra finch (Mooney, 1992; Spiro et al., 1999), song sparrow, and towhee (Meitzen et al., 2007a). We made very few stable recordings from GABAergic interneurons in RA [identified using the characteristics described by Spiro et al. (1999)], so here we focus solely on projection neurons.

\section{Breeding conditions increase the membrane time constant and capacitance}

Several intrinsic properties of projection neurons in RA differed significantly between treatment groups (Fig. $2 A, B$ ). The membrane time constant was increased significantly in neurons from birds exposed to the LD photoperiod and systemic T compared with those recorded from birds exposed to the SD photoperiod (Fig. $2 C)(p<0.005)$. Input resistance did not differ (Fig. 2D) $(p>0.05)$. Biocytin cell fills revealed that projection neurons in RA recorded from birds exposed to the LD photoperiod and systemic $\mathrm{T}$ had significantly larger soma areas compared with those exposed to the SD photoperiod (Fig. $2 E)(p<0.005)$, similar to previous studies (Brenowitz, 2004; Meitzen and Thompson, 2008). As predicted from the increase in soma size, the calculated capacitance of neurons from birds exposed to the 
A
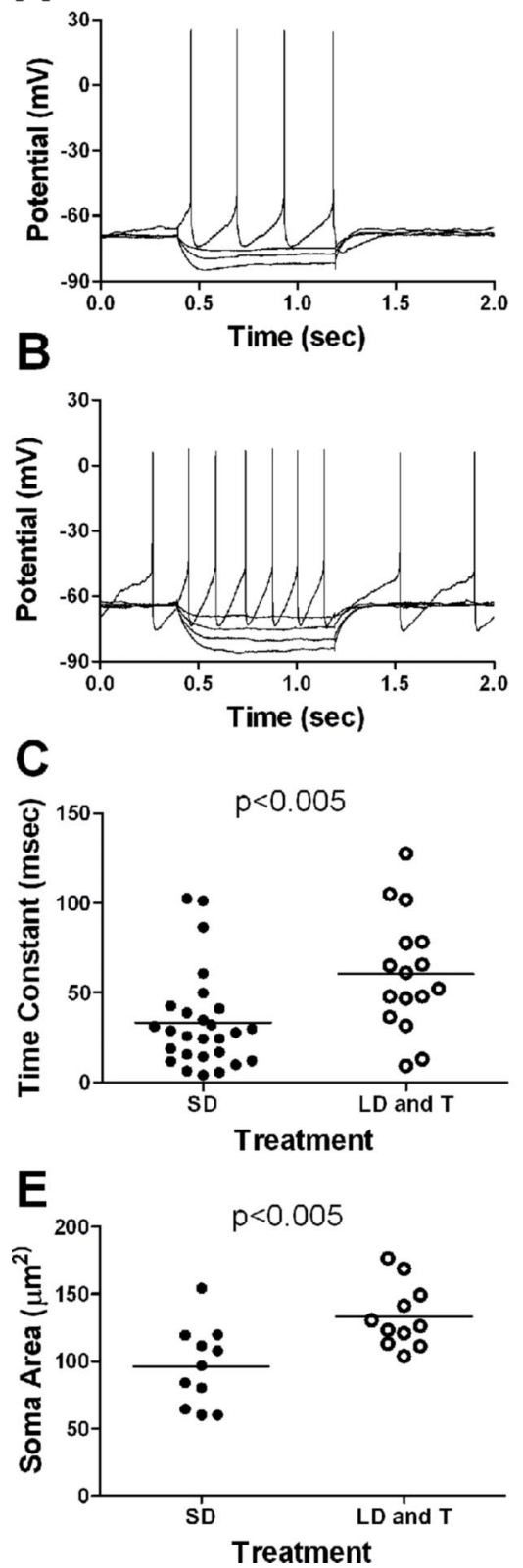
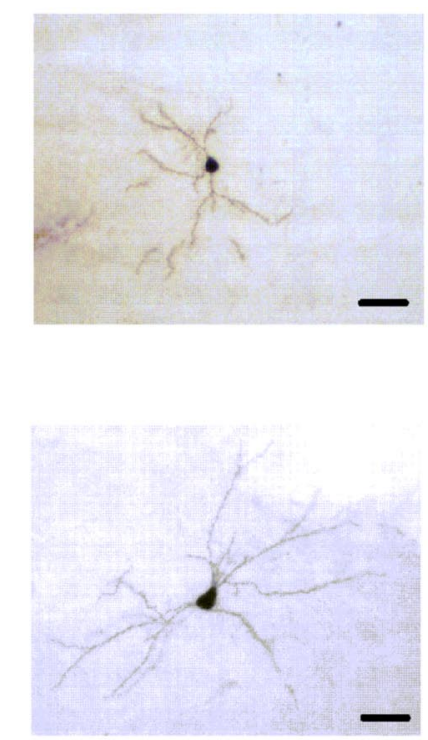

D

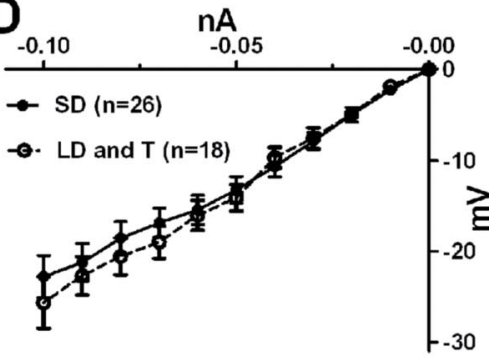

$\mathbf{F}$

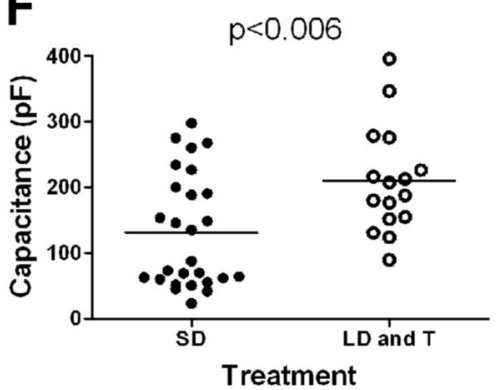

Figure 2. Breeding conditions change the intrinsic electrophysiological properties of projection neurons in RA. $\boldsymbol{A}$, Left, Voltage responses of a projection neuron in RA recorded from an SD photoperiod-exposed bird to a series of depolarizing and hyperpolarizing current injections. Current injections began at $0.4 \mathrm{~s}$ and ended at $1.2 \mathrm{~s}$. Injected current was $+0.03,-0.02,-0.04$, or $-0.08 \mathrm{nA}$. Right, Photomicrograph of a biocytin-labeled projection neuron in RA from an SD photoperiod-exposed bird. Scale bar, $30 \mu \mathrm{m}$. B, Left, Voltage responses to a series of depolarizing and hyperpolarizing current injections of a projection neuron in RA recorded from a bird exposed to the LD photoperiod and systemic T. Current injections began at $0.4 \mathrm{~s}$ and ended at $1.2 \mathrm{~s}$. Injected current was $+0.02,-0.02,-0.03,-0.04$, or $-0.05 \mathrm{nA}$. Right, Photomicrograph of a biocytin-labeled projection neuron in RA from an LD photoperiod- and systemic T-exposed bird. Scale bar, $30 \mu \mathrm{m}$. C, Membrane time constant (horizontal line indicates mean) increased in RA projection neurons from birds exposed to the LD photoperiod and systemic T. Each symbol represents one neuron. $\boldsymbol{D}$, Graph of the average steady-state voltage deflection from rest as a function of injected negative current (I-V plot) of RA projection neurons. $\boldsymbol{E}$, Soma area (horizontal line indicates mean) of RA projection neurons was larger in birds exposed to the LD photoperiod and systemic T. Each symbol represents one neuron. $\boldsymbol{F}$, Capacitance (horizontal line indicates mean) of RA projection neurons was larger in birds exposed to the LD photoperiod and systemic T. Each symbol represents one neuron.

LD photoperiod and systemic $\mathrm{T}$ was significantly larger than that of neurons from birds exposed to the SD photoperiod (Fig. $2 F$ ) $(p<0.006)$.

Breeding conditions increase spontaneous firing rates Many projection neurons in RA were spontaneously active in vitro (Fig. $3 A$ ), as described previously in zebra finches (Mooney,
1992; Spiro et al., 1999; Solis and Perkel, 2006), song sparrows (Meitzen et al., 2007a), towhees (Meitzen et al., 2007a), and white-crowned sparrows (Park et al., 2005; Meitzen et al., 2007b). Spontaneous firing rates were significantly elevated in birds exposed to the LD photoperiod and systemic $\mathrm{T}$ compared with birds exposed to the SD photoperiod (Fig. 3B; Table 2) $(p<0.001)$, similar to previous reports of breeding condition birds in both the laboratory (Park et al., 2005; Meitzen et al., 2007b) and the field (Meitzen et al., 2007a). The cumulative distributions of spontaneous firing rates also differed significantly (Fig. $3 C)(p<0.01)$. In contrast to previous reports (Mooney, 1992; Spiro et al., 1999), not all projection neurons in RA were spontaneously active. Whereas 27 of 33 projection neurons in RA were spontaneously active in birds exposed to the LD photoperiod and systemic T, only 16 of 33 projection neurons in RA in birds exposed to the SD photoperiod were spontaneously active (Table 2). Among nonspontaneously active neurons, the resting membrane potential was depolarized significantly in neurons from birds exposed to the LD photoperiod and systemic T compared with those from birds exposed to the SD photoperiod (Table 2$)(p<0.02)$. We found no differences in action potential shape between breeding conditions (Table 2) $(p>0.05)$.

\section{Breeding conditions increase evoked} firing rates

Action potential firing rates evoked by depolarizing current injection were significantly increased in birds exposed to the LD photoperiod and systemic $\mathrm{T}$ (Fig. $\left.4 A_{1,2}, B_{1,2}\right)$. We first compared evoked firing rates across groups by calculating an evoked firing rate to current (FI) curve (Fig. $4 C$ ) (evoked firing rate is the number of spikes evoked over the duration of the current injection). We calculated a linear regression for each curve (SD: $p<0.0001, r^{2}=$ 0.38; LD and T: $\left.p<0.0001, r^{2}=0.46\right)$ and found that the slope of the LD photoperiod and systemic $\mathrm{T}$ curve was increased significantly compared with the slope of the SD curve $(p<0.002)$. We also fit each curve with an exponential function rising to an asymptote $\left(Y_{\max }\right)$ and found that the fits differed significantly $(p<0.0001)$. $Y_{\max }$ was greater for neurons from birds treated with the LD photoperiod and systemic T (asymptote: SD, $30.66 \pm 2.79$ $\mathrm{Hz}$; $\mathrm{LD}$ and $\mathrm{T}, 49.46 \pm 6.79 \mathrm{~Hz})$, and the rate constant $(K)$ was higher for neurons from birds treated with the SD photoperiod (SD, $K=7.49 \pm 1.17 \mathrm{~Hz} ; \mathrm{LD}$ and $\mathrm{T}, K=5.70 \pm 1.26 \mathrm{~Hz}$ ). The cumulative distributions of the slopes of FI curves calculated for individual cells also differed significantly (Fig. 4D) $(p=0.005)$. Evoked firing rates 
Table 2. Properties of projection neurons recorded in RA

\begin{tabular}{lcc}
\hline Property & SD & LD and systemic T \\
\hline Resting membrane potential (mV) & $-65.94 \pm 1.32(17)^{\mathrm{a}}$, SF $(16)$ & $-58.97 \pm 1.92(6)^{\mathrm{b}}$, SF $(27)$ \\
Spontaneous firing rate (Hz) & $1.20 \pm 0.37(33)^{\mathrm{a}}$ & $6.67 \pm 1.23(33)^{\mathrm{b}}$ \\
Fl slope (Hz/nA) & $108.71 \pm 10.89(32)^{\mathrm{a}}$ & $163.65 \pm 23.60(18)^{\mathrm{b}}$ \\
Input resistance (MS) & $277.00 \pm 35.82(28)$ & $289.86 \pm 27.83(16)$ \\
Membrane time constant (ms) & $33.30 \pm 5.15(27)^{\mathrm{a}}$ & $60.50 \pm 8.09(16)^{\mathrm{b}}$ \\
Sag index & $0.05 \pm 0.01(14)$ & $0.05 \pm 0.01(22)$ \\
Capacitance (pF) & $131.07 \pm 16.61(27)^{\mathrm{a}}$ & $209.56 \pm 20.38(16)^{\mathrm{b}}$ \\
Soma area ( $\left.\mu \mathrm{m}^{2}\right)$ & $96.14 \pm 8.97(11)^{\mathrm{a}}$ & $133.16 \pm 7.08(11)^{\mathrm{b}}$ \\
AP threshold (mV) & $-45.31 \pm 1.22(33)$ & $-44.81 \pm 1.25(20)$ \\
AP half-width (ms) & $1.33 \pm 0.19(26)$ & $1.05 \pm 0.09(19)$ \\
AHP time to peak (ms) & $21.68 \pm 3.39(26)$ & $16.75 \pm 3.28(19)$ \\
AHP peak amplitude (mV) & $-16.88 \pm 1.36(26)$ & $-18.91 \pm 1.69(19)$ \\
\hline
\end{tabular}

Values are mean \pm SEM. Numbers in parentheses indicate sample size. Different superscript letters denote significant differences ( $p<0.02$ for all). Resting membrane potential was not measured in spontaneously firing (SF) neurons. The sag index is unitless. AP, Action potential.

of LD photoperiod and systemic T neurons were also increased significantly if individual FI slopes were compared using a two-tailed $t$ test $(p=0.02)$.

The increased evoked firing rate in RA neurons from birds exposed to the LD photoperiod and systemic T may be attributable to an increase in the steady-state firing rate. In response to depolarizing current injection, neurons from both SD and LD photoperiod- and systemic T-exposed animals maintained the same initial firing rate (Fig. $4 E$ ) (initial: firing rate of the first interval). LD photoperiod and systemic T neurons, however, exhibited consistently higher steady-state firing rates (Fig. $4 F$ ) (steady state: average firing rate over the last $400 \mathrm{~ms}$ of the current injection).

\section{Electrophysiological properties of HVC neurons}

Electrophysiological properties differ across cell types

HVC neurons could be placed into three categories distinguished by a combination of their intrinsic properties, action potential characteristics, and, when available, cellular morphology/axon trajectory, as described previously in the zebra finch (Fig. 5; Tables 3, 4) (Dutar et al., 1998; Kubota and Taniguchi, 1998; Mooney, 2000; Solis and Perkel, 2005). One category of neurons had characteristics similar to those of neurons that project to Area X (X projecting) in the zebra finch. These putative $\mathrm{X}$-projecting neurons in the white-crowned sparrow exhibited significantly longer membrane time constants and afterhyperpolarization (AHP) times-to-peak than RA-projecting neurons or interneurons ( $p<0.001$ for both, Tukey's post hoc test) (see Table 4 for complete ANOVA and Tukey's post hoc test statistics for this and other properties that differed significantly). Putative RA-projecting cells in white-crowned sparrow HVC were also typical of those recorded in the zebra finch, with significantly hyperpolarized resting membrane potentials compared with the other cell classes (Table 4, $p<0.001$ for both, Tukey's post hoc test). The last category of neurons recorded in white-crowned sparrow HVC typified GABAergic interneurons, exhibiting significantly shorter action potential half-widths (Table 4$)(p<$ $0.01, p<0.04$ compared with X- and RA-projecting cells, respectively, using Tukey's post hoc test), a higher sag index (Table 4) ( $p>0.05, p<0.04$ compared with X- and RA-projecting cells, respectively, using Tukey's post hoc test), and steeper FI curves compared with other cell classes (Table 4$)(p<0.001, p<0.04$ compared with X- and RA-projecting cells, respectively, using Tukey's post hoc test). All other measured cellular properties did not significantly differ between cell types (ANOVA, $p>0.05$ for all).

\section{A Cell-attached}

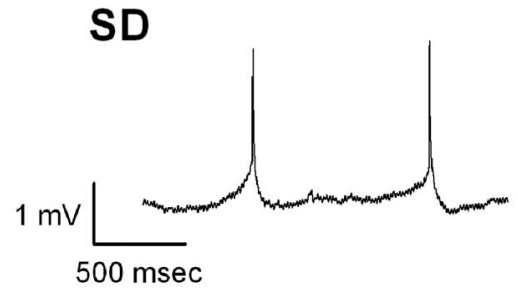

LD and T
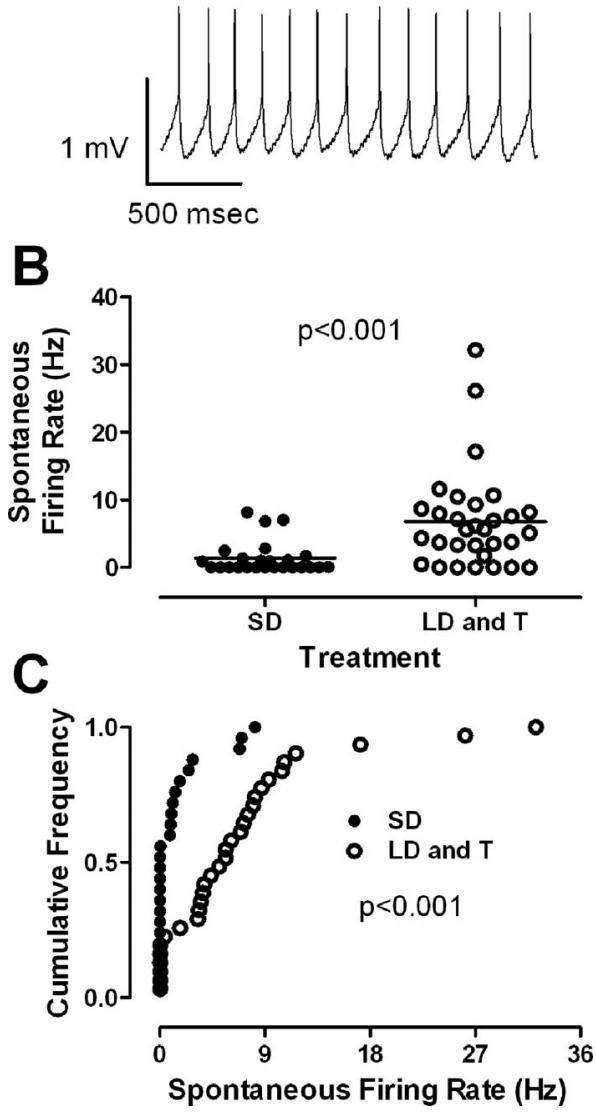

Figure 3. Breeding conditions increase the spontaneous firing rate of projection neurons in RA. $\boldsymbol{A}$, Representative on-cell recordings. Top, A projection neuron in RA from an SD photoperiod-exposed bird. Bottom, A projection neuron in RA from an LD photoperiod- and systemic T-exposed bird. $\boldsymbol{B}$, Spontaneous firing rate (horizontal line indicates mean) increased in birds exposed to the LD photoperiod and systemic T. Each symbol represents one neuron. $\boldsymbol{C}$, Cumulative frequency distributions of spontaneous firing rate for neurons from birds exposed to the LD photoperiod and systemic T (filled circles) or the SD photoperiod (open circles).

Electrophysiological properties are stable between breeding conditions

We found no significant changes in the electrophysiological properties of any single HVC cell type between breeding conditions (Table 3), and the interaction between cell type and breeding condition was not significant for any cellular property (ANOVA, $p>0.05$ for all). These negative results are likely not caused by a lack of statistical power (mean \pm SEM power of each factor and interaction; breeding condition, $0.26 \pm 0.07$; cell type, $0.65 \pm 0.12$; interaction, $0.05 \pm 0.00 ; n=11$ tests between two different breeding conditions and three different cell types, with each test having a different number of neurons across factors) (Table 3). 

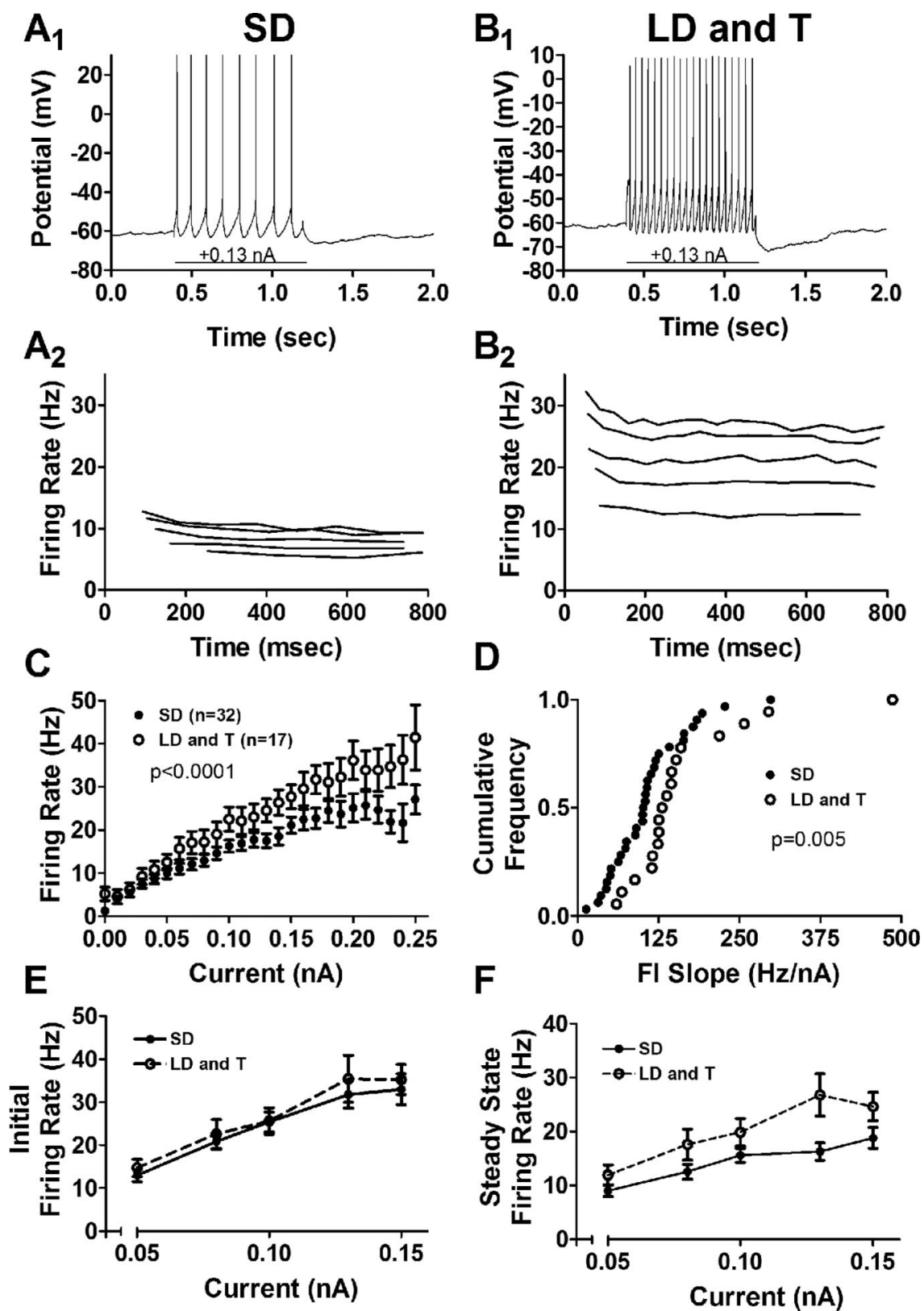

Figure 4. Breeding conditions increase the evoked firing rate of projection neurons in RA. $\boldsymbol{A}_{\boldsymbol{1}}, \boldsymbol{B}_{\boldsymbol{1}}$, Response of a neuron from an SD photoperiod-exposed bird $\left(\boldsymbol{A}_{\boldsymbol{7}}\right)$ and an LD photoperiod and systemic T bird $\left(\boldsymbol{B}_{\boldsymbol{1}}\right)$ to a depolarizing current injection of $0.13 \mathrm{nA}$. $\boldsymbol{A}_{2}, \boldsymbol{B}_{2}$, Instantaneous firing rate (reciprocal of interspike intervals) of projection neurons in RA during a series of positive current pulses $(0.05,0.08,1.00,1.30$, and $1.50 \mathrm{nA})$. These are the same neurons as in $\boldsymbol{A}_{\boldsymbol{1}}$ and $\boldsymbol{B}_{\boldsymbol{1}}$, respectively. $\boldsymbol{C}$, Evoked firing rate and injected current (FI) curve of RA projection neurons. $\boldsymbol{D}$, Cumulative frequency distribution of the slope for each individual $\mathrm{FI}$ curve from projection neurons in RA. $\boldsymbol{E}$, Average initial (reciprocal of the first interspike interval) firing rate. $\boldsymbol{F}$, Average steady-state (average firing rate over the last $400 \mathrm{~ms}$ of the current injection) firing rate.

\section{Discussion}

This study found that the electrophysiological properties of RA neurons change across breeding conditions, unlike neurons in HVC, whose properties are stable (Fig. 6). This is the first demonstration that the electrophysiological properties of songcontrol neurons change using intracellular recordings. In particular, the evoked and spontaneous firing rates, the membrane time constant, and capacitance are all increased in projection neurons in RA recorded from birds in breeding condition (i.e., birds exposed to the LD photoperiod and systemic T). This combination of stable and plastic electrophysiological properties will have consequences for circuit dynamics in the song-control sys- tem, enabling song to be more stereotyped during the breeding season.

These findings contribute to a developing model of how steroid hormones modulate the song-control system to produce changes in song behavior in adult whitecrowned sparrows (Brenowitz, 2004; Meitzen and Thompson, 2008). One principal finding of this body of work is that estrogenic and androgenic metabolites of T bind to receptors within HVC to act not only within the nucleus but also to induce trans-synaptic morphological and electrophysiological changes in RA (Brenowitz and Lent, 2001, 2002; Tramontin et al., 2003; Soma et al., 2004; Park et al., 2005; Meitzen et al., 2007b). This activation of estrogen and androgen receptors in HVC is necessary for increased song stereotypy, but not song rate (Meitzen et al., 2007b). Given that activation of estrogen and androgen receptors in HVC is necessary to drive changes in RA cellular properties and regulate song stereotypy (Brenowitz and Lent, 2001, 2002; Meitzen et al., 2007b), the changing cellular properties of RA neurons are more likely to mediate changes in song stereotypy than song rate. Additional support for this hypothesis comes from studies of brain areas outside of the traditional song-control system; lesions of the medial preoptic nucleus, for instance, can decrease song rate (Riters and Ball, 1999; Alger and Riters, 2006). Given this and other evidence (Ball, 2004; Meitzen and Thompson, 2008), here we focus on how the changing electrophysiological properties of song-control neurons might enable the song-control system motor pathway to produce more stereotyped song.

Membrane time constant and excitability of projection neurons in RA increase during breeding condition The electrophysiological properties of projection neurons in RA changed considerably across breeding conditions. Among the passive properties, the membrane time constant increased significantly in breeding condition birds, which could lengthen the time available to integrate synaptic input. This could be advantageous given that RA neurons must integrate temporally sparse inputs arriving from HVC to produce patterned action potentials that are temporally correlated with song production (McCasland, 1987; Yu and Margoliash, 1996; Chi and Margoliash, 2001; Hahnloser et al., 2002; Leonardo and Fee, 2005; Sober et al., 2008). The increased membrane time constant would be expected to increase temporal integration, which could be at odds with the improved spike timing that we would expect to accompany highly stereotyped song. Perhaps some compensatory mechanism takes over during song production to reduce the time constant and maintain precise spike timing; increased membrane 


\section{X-projecting}
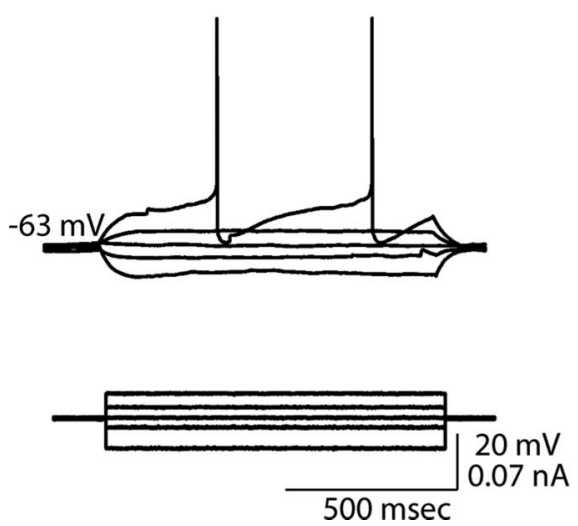

RA-projecting
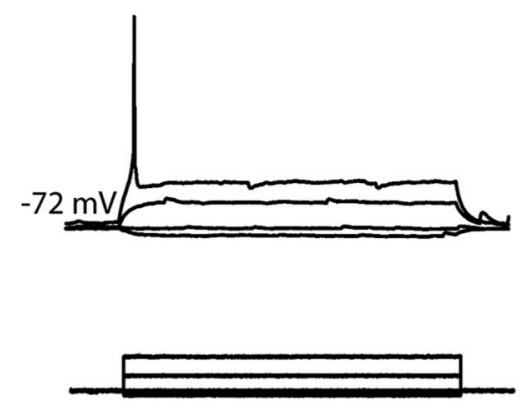

Interneuron

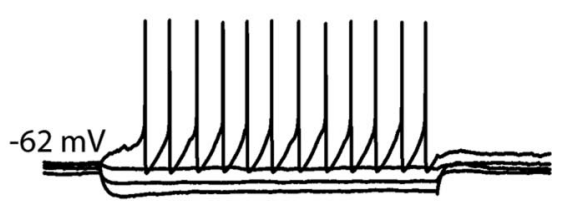

Figure 5. Electrophysiological properties of HVC neurons in white-crowned sparrows. HVC neurons fell into three different categories based on their cellular characteristics, similar to zebra finches. Left, Putative X-projecting neuron. Depolarizing current induces repetitive firing of action potentials, with relatively large, long-lasting AHPs. Hyperpolarizing currents revealed a longer membrane time constant than found in the other cell types. Middle, Putative RA-projecting neuron. The defining feature of this cell type was the resting membrane potential, which was much more hyperpolarized than the other cell types. Large amounts of depolarizing current were usually required to induce action potentials, which tended to be sparse. Right, Putative interneuron. Depolarizing currents tended to evoke high-frequency firing, with short-duration action potentials. Electrophysiological properties within a given cell type were static across breeding conditions. Voltage traces are representative and not averaged.

Table 3. Properties of HVC neurons

\begin{tabular}{|c|c|c|c|c|c|c|}
\hline \multirow[b]{2}{*}{ Property } & \multicolumn{2}{|l|}{ X-projecting cells } & \multicolumn{2}{|l|}{ RA-projecting cells } & \multicolumn{2}{|l|}{ Interneurons } \\
\hline & SD & LD and systemic T & SD & LD and systemic T & SD & LD and systemic T \\
\hline $\begin{array}{c}\text { Resting membrane } \\
\text { potential (mV) }\end{array}$ & $-62.24 \pm 4.37(8)$, SF (4) & $-64.52 \pm 1.59(7)$, SF (1) & $-75.04 \pm 3.60(8)$, SF (0) & $-77.17 \pm 1.84(13)$, SF (0) & $-58.34 \pm 0.92(6)$, SF (1) & $-59.69 \pm 3.90(5)$, SF (2) \\
\hline $\begin{array}{l}\text { Spontaneous firing } \\
\text { rate }(\mathrm{Hz})\end{array}$ & $0.99 \pm 0.43(12)$ & $1.00 \pm 1.00(8)$ & $0.00 \pm 0.00(8)$ & $0.00 \pm 0.00(13)$ & $1.54 \pm 1.54(7)$ & $1.61 \pm 1.04(7)$ \\
\hline Fl slope $(\mathrm{Hz} / \mathrm{nA})$ & $112.49 \pm 21.83(12)$ & $91.00 \pm 28.33(8)$ & $42.77 \pm 11.67(8)$ & $49.45 \pm 16.05(13)$ & $210.39 \pm 59.72(7)$ & $148.87 \pm 38.13(7)$ \\
\hline Input resistance $(\mathrm{M} \Omega$ ) & $287.99 \pm 62.04(11)$ & $192.30 \pm 28.17(8)$ & $323.79 \pm 60.55(7)$ & $215.74 \pm 22.88(13)$ & $254.97 \pm 46.61(7)$ & $142.39 \pm 27.83(7)$ \\
\hline $\begin{array}{l}\text { Membrane time con- } \\
\text { stant (ms) }\end{array}$ & $47.82 \pm 3.83(11)$ & $53.38 \pm 6.79(8)$ & $25.95 \pm 2.96(7)$ & $20.97 \pm 2.72(13)$ & $21.56 \pm 3.28(7)$ & $23.22 \pm 6.32(7)$ \\
\hline $\begin{array}{l}\text { Membrane capacitance } \\
\text { (pF) }\end{array}$ & $223.74 \pm 32.20(11)$ & $293.11 \pm 32.60(8)$ & $99.26 \pm 22.16(7)$ & $118.00 \pm 23.92(13)$ & $89.53 \pm 9.59(7)$ & $193.23 \pm 52.17(7)$ \\
\hline Sag index & $0.05 \pm 0.01(11)$ & $0.04 \pm 0.01(8)$ & $0.01 \pm 0.01(7)$ & $0.03 \pm 0.01(13)$ & $0.06 \pm 0.02(7)$ & $0.08 \pm 0.02(7)$ \\
\hline AP threshold (mV) & $-38.30 \pm 2.02(12)$ & $-41.43 \pm 1.25(8)$ & $-33.77 \pm 2.80(8)$ & $-38.80 \pm 0.93(13)$ & $-36.06 \pm 2.55(7)$ & $-38.17 \pm 0.98(7)$ \\
\hline AP half-width (ms) & $0.95 \pm 0.10(12)$ & $0.90 \pm 0.07(8)$ & $1.00 \pm 0.16(8)$ & $0.75 \pm 0.11(13)$ & $0.63 \pm 0.08(7)$ & $0.45 \pm 0.05(7)$ \\
\hline AHP time to peak (ms) & $27.53 \pm 1.01(12)$ & $32.20 \pm 4.86(8)$ & $2.09 \pm 0.27(8)$ & $4.41 \pm 1.71(13)$ & $2.37 \pm 0.50(7)$ & $3.61 \pm 1.30(7)$ \\
\hline $\begin{array}{l}\text { AHP peak amplitude } \\
\text { (mV) }\end{array}$ & $-16.38 \pm 1.44(12)$ & $-22.30 \pm 2.09(8)$ & $-20.58 \pm 2.64(8)$ & $-22.01 \pm 1.48(13)$ & $-20.49 \pm 1.04(7)$ & $-20.49 \pm 1.04(7)$ \\
\hline
\end{tabular}

Values are mean \pm SEM. Numbers in parentheses indicate sample size. No significant differences in cellular properties were found within a cell type between breeding conditions. Significant differences between cell types are found in Table 4. Resting membrane potential was not measured in spontaneously firing (SF) neurons. The sag index is unitless. AP, Action potential.

conductance, for example, could underlie the decreased rate of RA firing immediately before song (Yu and Margoliash, 1996; Hahnloser et al., 2002; Leonardo and Fee, 2005; Sober et al., 2008).

RA cellular capacitance also increased. This increase is expected given capacitance's relationship to the surface area of the plasma membrane (Johnston and $\mathrm{Wu}, 1995)$ and the increases in RA neuron soma size (Brenowitz, 2004) and dendritic field in breeding condition birds (Hill and DeVoogd, 1991). The increases in neuron size and capacitance are similar to those observed in steroid-sensitive neurons in other systems (Manabe et al., 1991; Yamaguchi et al., 2003). These similar hormone actions suggest a commonality between seasonality and sex differences: steroid sex hormones tend to increase neuronal size and capacitance. Neurons in different regions, however, may differ in whether an increase in neuron size leads to an increase in the time constant of the membrane (as in this study) or a decrease in input resistance [i.e., male Xenopus laryngeal motoneurons (Yamaguchi et al., 2003)]. In at least one case, however, the steroid sex hormone-induced increase in neuron size did not affect capacitance, input resistance, or the time constant [the sexually dimorphic avian hypoglossal motoneurons studied by Roberts et al. (2007)].

RA projection neurons also fired more rapidly under breeding conditions, perhaps making them more likely to produce an action potential in response to synaptic input. This increased excitability may make RA more sensitive to the sparse HVC input, ultimately increasing HVC control over RA firing patterns and decreasing spike-timing variability. This prediction should be tested in future experiments that compare the response of RA neurons in nonbreeding and breeding condition birds to synaptic input from HVC in vitro, or by comparing the activity of RA and HVC neurons during song production in vivo. RA's influence over its own targets could also increase, because of the linear FI curves of nXIIts motoneurons (Sturdy et al., 2003). It remains to be answered whether the difference in RA resting membrane potential fully explains the increase in excitability, or whether there are changes in active ionic conductances such as those in the 
Non-breeding

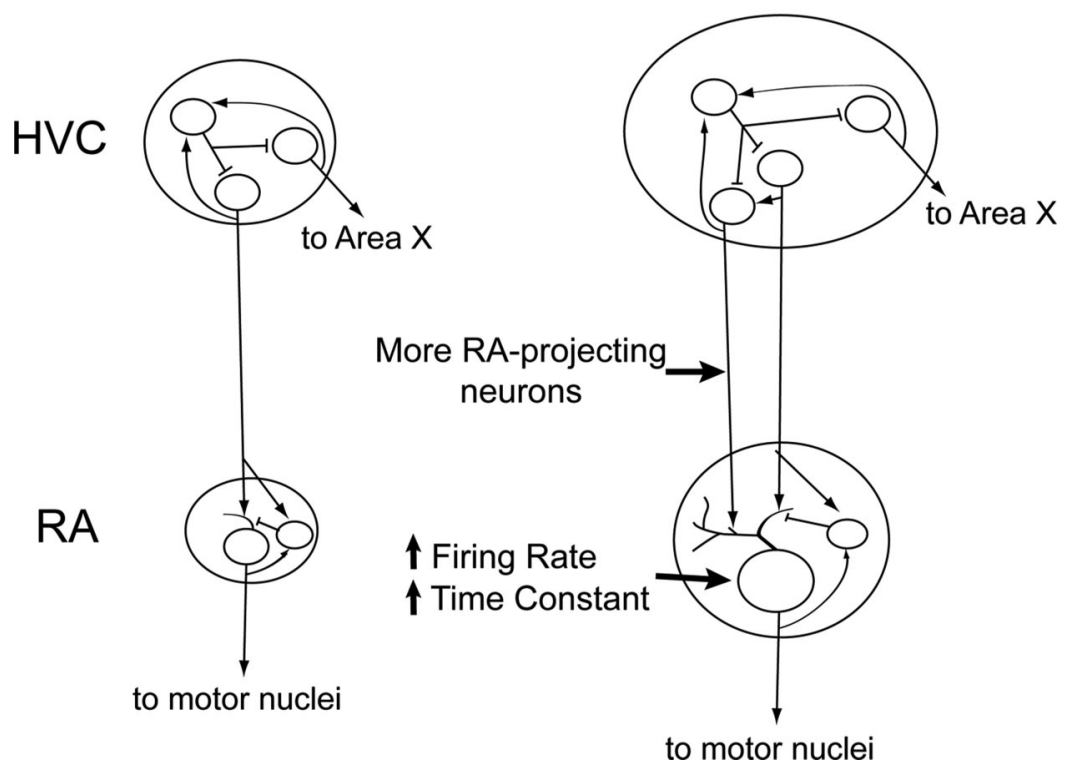

Figure 6. Illustration of how changes in the electrophysiological and morphological properties of individual HVC and RA neurons impact the song-control system motor pathway. In response to the LD photoperiod and systemic T, new RA-projecting neurons are added to HVC. We found no changes in any cell type's intrinsic electrophysiological properties in HVC. In RA, existing neurons grow larger somata and dendritic arbors, increasing capacitance and the membrane time constant, which may lengthen the time window for integrating synaptic input. Projection neurons in RA also increase their excitability (reflected by increases in their evoked and spontaneous firing rates), perhaps increasing the probability of action potential generation.

2005), which seems to be an adaptation related to production of the frog's speciesspecific vocalization (Zornik and Yamaguchi, 2008). All of these cases underscore that although it is common for hormones to manipulate cellular excitability or firing properties (Zakon, 1998), these changes are best interpreted in the context of a specific circuit.

Other unmeasured properties of RA neurons could change across breeding condition. In RA, synaptic mechanisms, in particular, are of interest, as expression of the NMDA subunit NR2B mRNA decreases in breeding condition canaries (Singh et al., 2003) and spines become denser and dendritic arbors lengthen in breeding condition birds (Hill and DeVoogd, 1991). This is reminiscent of the left hemisphere of the rat posterodorsal subnucleus of the medial amygdala. This region is sexually dimorphic, with male rats having an increased number of synapses and a higher frequency of miniature EPSCs (Cooke and Woolley, 2005b). RA, too, may have increased synaptic input. The structural changes in RA spine density and dendritic arbors also suggest that synaptic transmission in adult RA may be steroid sensitive, perhaps similar to rat hip-

Table 4. Significant differences between HVC cell types

\begin{tabular}{|c|c|c|}
\hline Property & Cell type & ANOVA test statistics \\
\hline Resting membrane potential (mV) & $\mathrm{RA}<\mathrm{X}^{*}{ }^{*} \operatorname{lnt}{ }^{*}$ & $\begin{array}{l}F_{(2,41)}=17.777 \\
p<0.001\end{array}$ \\
\hline Fl slope $(\mathrm{Hz} / \mathrm{nA})$ & $\operatorname{lnt}>\mathrm{RA}_{,}^{*} \mathrm{X}^{\ddagger}$ & $\begin{array}{l}F_{(2,49)}=9.775 \\
p<0.001\end{array}$ \\
\hline Membrane time constant (ms) & $X>\mathrm{RA}^{*}{ }^{*} \operatorname{lnt}{ }^{*}$ & $\begin{array}{l}F_{(2,47)}=26.862 \\
p<0.001\end{array}$ \\
\hline Membrane capacitance (pF) & $X>\mathrm{RA}_{1}^{*} \operatorname{lnt}^{\dagger}$ & $\begin{array}{l}F_{(2,47)}=13.140 \\
p<0.001\end{array}$ \\
\hline Sag index & $\operatorname{lnt}>\mathrm{RA}^{\dagger}$ & $\begin{array}{l}F_{(2,47)}=5.747 \\
p=0.006\end{array}$ \\
\hline AP half-width (ms) & $\operatorname{lnt}<\mathrm{X}_{,}^{\dagger} \mathrm{RA}^{\ddagger}$ & $\begin{array}{l}F_{(2,49)}=6.438 \\
p=0.003\end{array}$ \\
\hline AHP time to peak (ms) & $X>\mathrm{RA}^{*}{ }^{*} \ln \mathrm{t}^{*}$ & $\begin{array}{l}F_{(2,49)}=107.379 \\
p<0.001\end{array}$ \\
\hline
\end{tabular}

Significant differences between cell types are similar to those found in the zebra finch. For each given property, comparisons are shown as $a>b$, c, indicating that the mean value of that property for cell type " $a$ " is significantly larger than that of cell types " $b$ " and "c." Statistical significance was initially tested using a two-way ANOVA for each property, with breeding condition and cell type as the factors. A Tukey's post hoc test was then used to assess differences between cell types if $p<0.05$, with significance levels as follows: ${ }^{*} p<0.001 ;{ }^{\dagger} p<0.01 ;{ }^{\ddagger} p<0.04$.

electric organ of weakly electric teleosts (Stoddard et al., 2006). Hormone-induced changes in excitability are also found in other model systems. In the plainfin midshipman, for instance, the vocal motoneurons of the type I male are both larger and fire more rapidly than those of females and type II males, which vocalize much less (Bass and Baker, 1990). In rats, estrogen exposure reduces the absolute refractory period in stria terminalis neurons (Kendrick and Drewett, 1980) and modulates hippocampal excitability (Teyler et al., 1980). Unlike projection neurons in RA and the aforementioned examples, steroid sex hormones induce male frog motoneurons to be strongly adapting and fire at short latencies (Yamaguchi et al., 2003; Potter et al., pocampus (Hart et al., 2007) and juvenile songbird RA and LMAN (White et al., 1999). Other outstanding avenues of inquiry include whether hormones have rapid, rather than slow, effects on song-control neurons (Bass and Remage-Healey, 2008; Foradori et al., 2008).

\section{The electrophysiological properties of HVC neurons remain stable}

We found that the intrinsic electrophysiological properties of individual HVC cell types remain stable across breeding conditions. This is of interest because steroid hormones act on HVC to induce morphological and electrophysiological changes in RA and increase song stereotypy (Brenowitz, 2004; Meitzen and Thompson, 2008). HVC is part of the central pattern generator underlying song production (Vu et al., 1994; Vicario and Simpson, 1995; Solis and Perkel, 2005; Long and Fee, 2008), is necessary for normal song production in adult birds (Nottebohm et al., 1976; Simpson and Vicario, 1990; Aronov et al., 2008), and contains projection neurons whose activity is temporally coordinated with song production (McCasland, 1987; Yu and Margoliash, 1996; Chi and Margoliash, 2001; Hahnloser et al., 2002; Leonardo and Fee, 2005; Kozhevnikov and Fee, 2007). The RAprojecting neurons, in particular, fire rarely during song production, usually bursting at a particular time, once per motif (Hahnloser et al., 2002). This sparse spiking behavior may depend critically on the unique electrophysiological properties of RAprojecting neurons, and it may be advantageous for these properties to remain stable across breeding conditions, especially considering that new RA-projecting neurons are incorporated into HVC (Alvarez-Buylla et al., 1988; Tramontin et al., 1998; Tramontin and Brenowitz, 1999; Scotto-Lomassese et al., 2007). HVC may thus not necessarily increase control over motor output by changing the intrinsic electrophysiological properties of its 
cells, but instead by adding more RA-projecting neurons and perhaps other cell types. These additions increase the number of synapses made in RA by HVC neurons, which might make HVC neurons more influential in directing RA spiking. Song behavior could also be influenced by other, unmeasured properties of HVC neurons, including gap junctions, which increase in female canaries exposed to T (Gahr and Garcia-Segura, 1996).

\section{Conclusion}

We recorded from neurons in RA and HVC across breeding conditions and found that although the electrophysiological properties of RA neurons change, those of HVC neurons remain stable. These plastic and stable electrophysiological properties of RA and HVC neurons, respectively, may underlie increased song stereotypy during the breeding season.

\section{References}

Alger SJ, Riters LV (2006) Lesions to the medial preoptic nucleus differentially affect singing and nest box-directed behaviors within and outside of the breeding season in European starlings (Sturnus vulgaris). Behav Neurosci 120:1326-1336.

Alvarez-Buylla A, Theelen M, Nottebohm F (1988) Birth of projection neurons in the higher vocal center of the canary forebrain before, during, after song learning. Proc Natl Acad Sci U S A 85:8722-8726.

Aronov D, Andalman AS, Fee MS (2008) A specialized forebrain circuit for vocal babbling in the juvenile songbird. Science 320:630-634.

Ball GF (2004) Pathways for hormonal influence of birdsong. In: Nature's music, The science of birdsong (Marler P, Slabbekoorn H, eds), p 254. San Diego: Elsevier.

Ball GF, Auger CJ, Bernard DJ, Charlier TD, Sartor JJ, Riters LV, Balthazart J (2004) Seasonal plasticity in the song control system: multiple brain sites of steroid hormone action and the importance of variation in song behavior. Ann N Y Acad Sci 1016:586-610.

Bass AH, Baker R (1990) Sexual dimorphisms in the vocal control system of a teleost fish: morphology of physiologically identified neurons. J Neurobiol 21:1155-1168.

Bass AH, Remage-Healey L (2008) Central pattern generators for social vocalization: androgen-dependent neurophysiological mechanisms. Horm Behav 53:659-672.

Bass AH, Zakon HH (2005) Sonic and electric fish: at the crossroads of neuroethology and behavioral neuroendocrinology. Horm Behav 48:360-372.

Baufreton J, Atherton JF, Surmeier DJ, Bevan MD (2005) Enhancement of excitatory synaptic integration by GABAergic inhibition in the subthalamic nucleus. J Neurosci 25:8505-8517.

Blanton MG, Lo Turco JJ, Kriegstein AR (1989) Whole cell recording from neurons in slices of reptilian and mammalian cerebral cortex. J Neurosci Methods 30:203-210.

Brenowitz EA (2004) Plasticity of the adult avian song control system. Ann N Y Acad Sci 1016:560-585.

Brenowitz EA, Lent K (2001) Afferent input is necessary for seasonal growth and maintenance of adult avian song control circuits. J Neurosci 21:2320-2329.

Brenowitz EA, Lent K (2002) Act locally and think globally: intracerebral testosterone implants induce seasonal-like growth of adult avian song control circuits. Proc Natl Acad Sci U S A 99:12421-12426.

Chi Z, Margoliash D (2001) Temporal precision and temporal drift in brain and behavior of zebra finch song. Neuron 32:899-910.

Cooke BM, Woolley CS (2005a) Gonadal hormone modulation of dendrites in the mammalian CNS. J Neurobiol 64:34-46.

Cooke BM, Woolley CS (2005b) Sexually dimorphic synaptic organization of the medial amygdala. J Neurosci 25:10759-10767.

Del Negro C, Lehongre K, Edeline JM (2005) Selectivity of canary HVC neurons for the bird's own song: modulation by photoperiodic conditions. J Neurosci 25:4952-4963.

Ding L, Perkel DJ (2002) Dopamine modulates excitability of spiny neurons in the avian basal ganglia. J Neurosci 22:5210-5218.

Dutar P, Vu HM, Perkel DJ (1998) Multiple cell types distinguished by physiological, pharmacological and anatomical properties in nucleus HVc of the adult zebra finch. J Neurophysiol 80:1828-1838.
Farries MA, Perkel DJ (2000) Electrophysiological properties of avian basal ganglia neurons recorded in vitro. J Neurophysiol 84:2502-2513.

Farries MA, Perkel DJ (2002) A telencephalic nucleus essential for song learning contains neurons with physiological characteristics of both striatum and globus pallidus. J Neurosci 22:3776-3787.

Farries MA, Meitzen J, Perkel DJ (2005) Electrophysiological properties of neurons in the basal ganglia of the domestic chick: conservation and divergence in the evolution of the avian basal ganglia. J Neurophysiol 94:454-467.

Foradori CD, Weiser MJ, Handa RJ (2008) Non-genomic actions of androgens. Front Neuroendocrinol 29:169-181.

Gahr M, Garcia-Segura LM (1996) Testosterone-dependent increase of gap-junctions in HVC neurons of adult female canaries. Brain Res 712:69-73.

Gale SD, Perkel DJ (2006) Physiological properties of zebra finch ventral tegmental area and substantia nigra pars compacta neurons. J Neurophysiol 96:2295-2306.

Hahnloser RH, Kozhevnikov AA, Fee MS (2002) An ultra-sparse code underlies the generation of neural sequences in a songbird. Nature 419:65-70.

Hart SA, Snyder MA, Smejkalova T, Woolley CS (2007) Estrogen mobilizes a subset of estrogen receptor-alpha-immunoreactive vesicles in inhibitory presynaptic boutons in hippocampal CA1. J Neurosci 27:2102-2111.

Herrmann K, Arnold AP (1991) The development of afferent projections to the robust archistriatal nucleus in male zebra finches: a quantitative electron microscopic study. J Neurosci 11:2063-2074.

Hill KM, DeVoogd TJ (1991) Altered daylength affects dendritic structure in a song-related brain region in red-winged blackbirds. Behav Neural Biol 56:240-250.

Johnston D, Wu SM (1995) Foundations of cellular neurophysiology. Cambridge, MA: MIT.

Kendrick KM, Drewett RF (1980) Testosterone-sensitive neurones respond to oestradiol but not to dihydrotestosterone. Nature 286:67-68.

Kozhevnikov AA, Fee MS (2007) Singing-related activity of identified HVC neurons in the zebra finch. J Neurophysiol 97:4271-4283.

Kubota M, Taniguchi I (1998) Electrophysiological characteristics of classes of neuron in the HVc of the zebra finch. J Neurophysiol 80:914-923.

Leonardo A, Fee MS (2005) Ensemble coding of vocal control in birdsong. J Neurosci 25:652-661.

Long MA, Fee MS (2008) Using temperature to analyse temporal dynamics in the songbird motor pathway. Nature 456:189-194.

Manabe T, Araki I, Takahashi T, Kuno M (1991) Membrane currents recorded from sexually dimorphic motoneurones of the bulbocavernosus muscle in neonatal rats. J Physiol 440:419-435.

McCasland JS (1987) Neuronal control of bird song production. J Neurosci 7:23-39.

Meitzen J, Thompson CK (2008) Seasonal-like growth and regression of the avian song control system: neural and behavioral plasticity in adult male Gambel's white-crowned sparrows. Gen Comp Endocrinol 157:259-265.

Meitzen J, Perkel DJ, Brenowitz EA (2007a) Seasonal changes in intrinsic electrophysiological activity of song control neurons in wild song sparrows. J Comp Physiol A Neuroethol Sens Neural Behav Physiol 193:677-683.

Meitzen J, Moore IT, Lent K, Brenowitz EA, Perkel DJ (2007b) Steroid hormones act transsynaptically within the forebrain to regulate neuronal phenotype and song stereotypy. J Neurosci 27:12045-12057.

Meitzen J, Thompson CK, Choi H, Perkel DJ, Brenowitz EA (2009) Time course of changes in Gambel's white-crowned sparrow song behavior following transitions in breeding condition. Horm Behav 55:217-227.

Mooney R (1992) Synaptic basis for developmental plasticity in a birdsong nucleus. J Neurosci 12:2464-2477.

Mooney R (2000) Different subthreshold mechanisms underlie song selectivity in identified $\mathrm{HVc}$ neurons of the zebra finch. J Neurosci 20:5420-5436

Mooney R, Konishi M (1991) Two distinct inputs to an avian song nucleus activate different glutamate receptor subtypes on individual neurons. Proc Natl Acad Sci U S A 88:4075-4079.

Nottebohm F (1981) A brain for all seasons: cyclical anatomical changes in song control nuclei of the canary brain. Science 214:1368-1370.

Nottebohm F, Stokes TM, Leonard CM (1976) Central control of song in the canary, Serinus canarius. J Comp Neurol 165:457-486.

Park KH, Meitzen J, Moore IT, Brenowitz EA, Perkel DJ (2005) Seasonal- 
like plasticity of spontaneous firing rate in a songbird pre-motor nucleus. J Neurobiol 64:181-191.

Person AL, Perkel DJ (2005) Unitary IPSPs drive precise thalamic spiking in a circuit required for learning. Neuron 46:129-140.

Pfaff DW, Kow LM, Loose MD, Flanagan-Cato LM (2008) Reverse engineering the lordosis behavior circuit. Horm Behav 54:347-354.

Potter KA, Bose T, Yamaguchi A (2005) Androgen-induced vocal transformation in adult female African clawed frogs. J Neurophysiol 94:415-428.

Reiner A, Perkel DJ, Bruce LL, Butler AB, Csillag A, Kuenzel W, Medina L, Paxinos G, Shimizu T, Striedter G, Wild M, Ball GF, Durand S, Guturkun O, Lee DW, Mello CV, Powers A, White SA, Hough G, Kubikova L (2004) Revised nomenclature for avian telencephalon and some related brainstem nuclei. J Comp Neurol 473:377-414.

Riters LV, Ball GF (1999) Lesions to the medial preoptic area affect singing in the male European starling (Sturnus vulgaris). Horm Behav 36:276-286.

Roberts TF, Wild JM, Kubke MF, Mooney R (2007) Homogeneity of intrinsic properties of sexually dimorphic vocal motoneurons in male and female zebra finches. J Comp Neurol 502:157-169.

Roberts TF, Klein ME, Kubke MF, Wild JM, Mooney R (2008) Telencephalic neurons monosynaptically link brainstem and forebrain premotor networks necessary for song. J Neurosci 28:3479-3489.

Schlinger BA, London SE (2006) Neurosteroids and the songbird model system. J Exp Zoolog A Comp Exp Biol 305:743-748.

Scotto-Lomassese S, Rochefort C, Nshdejan A, Scharff C (2007) HVC interneurons are not renewed in adult male zebra finches. Eur J Neurosci 25:1663-1668.

Sengelaub DR, Forger NG (2008) The spinal nucleus of the bulbocavernosus: firsts in androgen-dependent neural sex differences. Horm Behav 53:596-612.

Simpson HB, Vicario DS (1990) Brain pathways for learned and unlearned vocalizations differ in zebra finches. J Neurosci 10:1541-1556.

Singh TD, Heinrich JE, Wissman AM, Brenowitz EA, Nordeen EJ, Nordeen KW (2003) Seasonal regulation of NMDA receptor NR2B mRNA in the adult canary song system. J Neurobiol 54:593-603.

Sizemore M, Perkel DJ (2008) Noradrenergic and GABA B receptor activation differentially modulate inputs to the premotor nucleus RA in zebra finches. J Neurophysiol 100:8-18.

Smith GT, Brenowitz EA, Wingfield JC, Baptista LF (1995) Seasonal changes in song nuclei and song behavior in Gambel's white-crowned sparrows. J Neurobiol 28:114-125.

Smith GT, Brenowitz EA, Wingfield JC (1997) Roles of photoperiod and testosterone in seasonal plasticity of the avian song control system. J Neurobiol 32:426-442.

Sober SJ, Wohlgemuth MJ, Brainard MS (2008) Central contributions to acoustic variation in birdsong. J Neurosci 28:10370-10379.

Solis MM, Perkel DJ (2005) Rhythmic activity in a forebrain vocal control nucleus in vitro. J Neurosci 25:2811-2822.

Solis MM, Perkel DJ (2006) Noradrenergic modulation of activity in a vocal control nucleus in vitro. J Neurophysiol 95:2265-2276.

Soma KK, Tramontin AD, Featherstone J, Brenowitz EA (2004) Estrogen contributes to seasonal plasticity of the adult avian song control system. J Neurobiol 58:413-422.

Spiro JE, Dalva MB, Mooney R (1999) Long-range inhibition within the zebra finch song nucleus RA can coordinate the firing of multiple projection neurons. J Neurophysiol 81:3007-3020.

Stark LL, Perkel DJ (1999) Two-stage, input-specific synaptic maturation in a nucleus essential for vocal production in the zebra finch. J Neurosci 19:9107-9116.

Stoddard PK, Zakon HH, Markham MR, McAnelly L (2006) Regulation and modulation of electric waveforms in gymnotiform electric fish. J Comp Physiol A Neuroethol Sens Neural Behav Physiol 192:613-624.

Sturdy CB, Wild JM, Mooney R (2003) Respiratory and telencephalic modulation of vocal motor neurons in the zebra finch. J Neurosci 23:1072-1086.

Teyler TJ, Vardaris RM, Lewis D, Rawitch AB (1980) Gonadal steroids: effects on excitability of hippocampal pyramidal cells. Science 209:1017-1018.

Tramontin AD, Brenowitz EA (1999) A field study of seasonal neuronal incorporation into the song control system of a songbird that lacks adult song learning. J Neurobiol 40:316-326.

Tramontin AD, Brenowitz EA (2000) Seasonal plasticity in the adult brain. Trends Neurosci 23:251-258.

Tramontin AD, Smith GT, Breuner CW, Brenowitz EA (1998) Seasonal plasticity and sexual dimorphism in the avian song control system: stereological measurement of neurondensity and number. J Comp Neurol 396:186-192.

Tramontin AD, Hartman VN, Brenowitz EA (2000) Breeding conditions induce rapid and sequential growth in adult avian song circuits: a model of seasonal plasticity in the brain. J Neurosci 20:854-861.

Tramontin AD, Perfito N, Wingfield JC, Brenowitz EA (2001) Seasonal growth of song control nuclei precedes seasonal reproductive development in wild adult song sparrows. Gen Comp Endocrinol 122:1-9.

Tramontin AD, Wingfield JC, Brenowitz EA (2003) Androgens and estrogens induce seasonal- like growth of song nuclei in the adult songbird brain. J Neurobiol 57:130-140.

Vicario DS (1991) Organization of the zebra finch song control system: II. Functional organization of outputs from nucleus Robustus archistriatalis. J Comp Neurol 309:486-494.

Vicario DS, Simpson HB (1995) Electrical stimulation in forebrain nuclei elicits learned vocal patterns in songbirds. J Neurophysiol 73:2602-2607.

Vu ET, Mazurek ME, Kuo YC (1994) Identification of a forebrain motor programming network for the learned song of zebra finches. J Neurosci 14:6924-6934.

White SA, Livingston FS, Mooney R (1999) Androgens modulate NMDA receptor-mediated EPSCs in the zebra finch song system. J Neurophysiol 82:2221-2234.

Wild JM (1993) The avian nucleus retroambigualis: a nucleus for breathing, singing and calling. Brain Res 606:319-324.

Wingfield JC, Farner D (1978) The annual cycle of plasma irLH and steroid hormones in feral populations of the white-crowned sparrow, Zonotrichia leucophrys gambelii. Biol Reprod 19:1046-1056.

Wingfield JC, Moore MC (1987) Hormonal, social, and environmental factors in the reproductive biology of free-living male birds. In: Psychobiology of reproductive behavior: an evolutionary perspective (Crews D, ed), pp 149-175. Englewood Cliffs, NJ: Prentice-Hall.

Yamaguchi A, Kaczmarek LK, Kelley DB (2003) Functional specialization of male and female vocal motoneurons. J Neurosci 23:11568-11576.

Yu AC, Margoliash D (1996) Temporal hierarchical control of singing in birds. Science 273:1871-1875.

Zakon H (1998) The effects of steroid hormones on electrical activity of excitable cells. Trends Neurosci 21:202-207.

Zar JH (1999) Biostatistical analysis. Upper Saddle River, NJ: Prentice-Hall.

Zornik E, Yamaguchi A (2008) Sexually differentiated central pattern generators in Xenopus laevis. Trends Neurosci 31:296-302. 